University for Business and Technology in Kosovo

UBT Knowledge Center

UBT International Conference

2014 UBT International Conference

Nov 8th, 10:00 AM - 10:15 AM

\title{
The financial crisis: origins, causes and conclusions
}

\author{
Eneida Permeti \\ University of Tirana, permeti.enedia@yahoo.com \\ Blerta Mjeda \\ University of Tirana, bmjeda@epoka.edu.al
}

Follow this and additional works at: https://knowledgecenter.ubt-uni.net/conference

Part of the Business Commons

\section{Recommended Citation \\ Permeti, Eneida and Mjeda, Blerta, "The financial crisis: origins, causes and conclusions" (2014). UBT International Conference. 37. \\ https://knowledgecenter.ubt-uni.net/conference/2014/all-events/37}

This Event is brought to you for free and open access by the Publication and Journals at UBT Knowledge Center. It has been accepted for inclusion in UBT International Conference by an authorized administrator of UBT Knowledge Center. For more information, please contact knowledge.center@ubt-uni.net. 


\title{
The financial crisis: origins, causes and conclusions
}

\author{
${ }^{1}$ Eneida Permeti, ${ }^{2}$ Blerta Mjeda \\ University of Tirana, Albania \\ Department of Statistics \\ ${ }^{1}$ permeti.enedia@yahoo.com, ${ }^{2}$ bmjeda@epoka.edu.al
}

\begin{abstract}
The crisis in recent years took start in response to a crisis of the real estate market in the United States in 2007. The year 2009 has seen an economic crisis and between 2010 and 2011 it was known the spreading of the crisis sovereign debt and public finances of many countries. The financial markets failed in their main task: the allocation of risk. The products and services traded in the financial market are characterized by the immateriality and legal complexity. It means a high uncertainty degree and a high risk. Therefore is very important to protect the investors and this means: give them the right information, right legislation, market confidence and a product that respond to their needs. The crisis causes are: weaknesses in the regulatory, malfunction of the rating agencies, political errors and conflicts of interest. This means that we need: more rules, more capital, less debt, more transparency. The financial markets and the economy have always moved in harmony and savers have undertaken a countercyclical behavior, against trend or against the cycle and for investing in financial markets with the probability in favor we need a map that comes from the statistics.
\end{abstract}

Keywords: financial market, risk, crisi, statistics, future.

\section{Introduction}

Since the summer of 2007, the world was shocked by the most severe financial crisi in history. Losses are now conted in thousands of dollars. In 2008, the stock exchanges have lost nearly 30 trillon of dollars. The economic recovery is a matter for the Central Banks and the govenrments. It is important to know the causes of the recession for finding the best maneuvers: making mistakes in managing a crisis can have disastrous consequences and prolong the duration.

\subsection{The collapse causes}

In each country, the economic activity is subject to cyclical variations. The economic cycle goes through different phases : phase of growth (the GDP icreases rapidly), phase of recession (the GDP decreases), phase of depression ( the production stagnates and the unempoyement remains at high levels), phase of recovery ( the GDP starts to increase again).

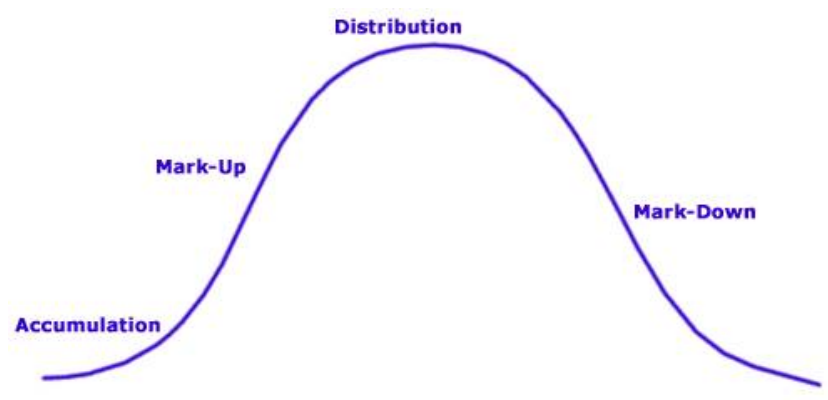

Figure 1 Phases of market

Source: www.proiezioniborsa.com

The financial crisis has had its epicenter in the United States, which over the past 20 years had a very fast economic growth. American families were consuming more than they produced and this has been facilitated by the globalization, which allowed the borrowing from other states and by the fact that the 
Federal Reserve System has kept interest rates very lows. The debt of the american families exceeds the disposable income and in 2007 exceeds the 140\%. In the nineties, the stock market was growing quickly because the United States offered attractive investments and the foreign investors were attracted by the geat gains that the stock market seemed to be able to offer. This situation has influenced the burst of the speculative bubble in the stock market in 2001. The Fed decided to decrease the interest rate, but still began to grow three large speculative bubbles:

- The stocks bubble

- The menger and acquisitions one

- The houses one

Being in a recession, the Fed urged the citizens to use the cheap credit (the subprime mortgages) for home ownership. In 2004, the Department of Housing and Urban Development gave a clear mandate to Fannie and Freddie to increase the high-risk loans. In 2003, a law was passed "American Dream Downpayment Act", which subsidized the purchase of homes financed entirely with loans. It was a subsidy to irresponsible purchases. Thus, the housing market was on the rise.

A bank earns more if is granting more loans, but the bank didn't calculate the high debtor risk of insolvency, because in the event that the costomer could not pay, they lost the advance payment and the house, but the economic damage reamins to the bank that are owners of homes and have liquidity problems. So, why the banks would have had to grant their liquidity to people of whorm harbored little confidence?

The anwer is: securization. It is a technique that consist in the transformation of loans into securities that can be sold on the markets to a large number of investors, thus transferring the risk. Various studies document that in this way, are created situations that should not exist in an efficient financial system: information asymmetries, moral hazard, adverse selection. The houshold debts were "packaged" and sold to companies (Special Purpose Vehicle) that transformed them in bonds. The issue was arranged by an investment bank. According to an IMF report, $75 \%$ of subprime mortgages were turned into securities and $80 \%$ were classified with triple "A". For different reasons, by these securities are produced other securities, derivatives and so on. Then, the investors buy the derivative securities without a clear idea of the underlying. However, these products have a huge demand, because they offere higher returns then the govenrment bonds of the same rating category. The institutional investors, which by law can only invest in securities with triple-A rated, agree very well these new opportunities for investment. So, the loans supply increased. The enormous mass of financial instruments is diffused all over the world. At the microeconomic level, an american borrows with the bank to buy home and at the macroeconomic level, the United States get into debt to the rest of the world, yielding products of finacial innovation. The american government was offering new securities (put into circulation through two government agencies Fannie Mae and Freddie Mac), so the institutions felt more secure.

The american liberal ideology, according to which, rational individuals interact in perfect markets, and therefore the markets are self-regulated, did not conceive that a market might fail and therefore do not consider the fact that in the event of a crisis, the warranty offered would bring a rise in the public debt. Other institutions began to follow the example of the banks and the market looked like an inverted pyramid: an incredible volume of risky investment are held on a pedestal of capital too small. [1]

An idea of the fragility of the balance sheets of the banks you can have with these data: on a stock of 26 trillion dollars of bonds in circulation in the United States, about half of them are real estate loans. Of the real estate loans, $10 \%$ were granted to families through subprime mortgages. A half, for a value of 600 billion dollars were repurchased to laverage from the banks, because a real estate loan depends by the value of the house, which was purchased thanks to it. Their value increased by the housing bubble. Due to their high risk, the subprime mortgages guaranted high interest rates.

The Finance was changing, but the financial regulation was not adequate to all this and therefor, there have been serious consequences. The Control Authorities have allowed banks to increase the laverage, so the debt. The monitoring was done on the basis of Value at Risk, without considering the sistemic risk.

Even the rating agencies have their own responsabilities, because they have granted many valutation "AAA". The state institutions like Fannie Mae and Freddie Mac passed into the hands of managers that headed them like private institutions taking very high risks with the politicans protection. 


\subsection{From the financial crisis to the economic recession}

The american financial situation has been taken as a model in other countries and this fact gave birth to the economic crisis:

- On 7 February 2007 the" New Century" bank launched a useful alarm.

- On 8 June 2007, Wall Street lost 1.5\%.

- In february 2008, the "Nothern Rock" bank is the first "victim " in Grand Britain and is saved by the state.

- On 15 march 2008, Usa Bear Stearns ended in a liquidity crisis; Jp Morgan with the support of the Federal Reserve, saved it.

- On 15 September 2008, Lehman Brothers (that had been in crisis for a few months) ends up in bankruptcy. The government did not save it; start so a stock market crash.

- On 19 September, the minister Paulson announced a 700 billion dollars bailout.

- The end of 2008: the financial crisis becomes an economic crisis. Many countries end up in a recession.

The financial markets have failed in their primary task: the risk allocation, for regulation errors of authorities responsables for monitoring and politicans errors. From the beginning, the crisis has been managed without having clears causes

and clear direction. On 8 august 2007, all the interbank rates shoot up, against all expectations. The reasons of why the banks suddenly demand higher rates to lend to other banks, could be two: a reduction of the liquidity supply or an increase of perceived risk. In both cases, the situation is serious and indicates a market stress. The central banks intervene in support of the principal global banks. In a few days, the Fed, the ECB and other central banks make avaible to the largest bank in the world a very big amount of money, but the intervention have little effect and at that time the public begins to understand the gravity of the situation. The collapse becomes continous and the central banks continue to put liquidity in the economy and to low the interest rates. In Europe, the major failures in financial terms were in England, France, Switzerland and Germany. The financial crisis started in America and it has exported its toxic products all over the world. [2] [3]

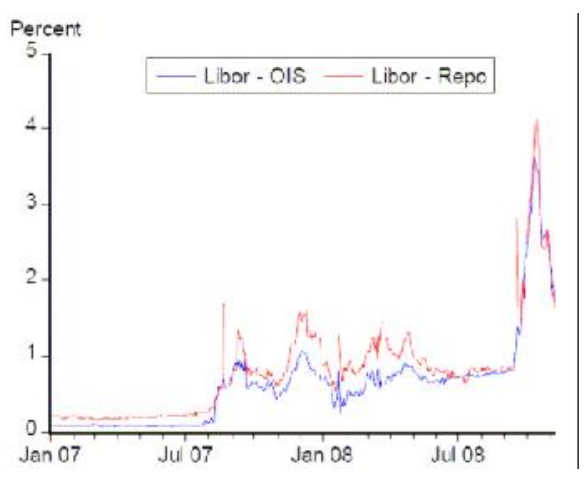

Figure 2 The interbank rates (United States)

Source: J.B. Taylor, Novembre 2008[4]

\subsection{The mistakes to not repeat}

Among the negative effects of the economic crisis, it is not to overlook the loss of confidence of anybody to the markets. Those who have few resources prefere saving its, because exist the uncertainity for the future and those who have many resources doesn't invest because he think that them would go to waste. 
Do not exist ideal rules to avoid any crisis, but we should consider four important points: more rules, more capital, less debt, more transparency. This means:

- Forcing banks to hold more capital in order to ensure a greater risk hedging.

- Require banks to maintain a certain amount of risk.

- Prevent banks maximize their profits, taking advantage of the financial ignorance of the costomers.

- The new regulation should measure the risk considering the sistemic risk.

- It is necessary to weaken the role of the rating agencies.

- The Otc derivatives should be intermediated by the Clearing House.

- Must be strengthened the international cooperation, assigning crucial role to the international authorities such as the Basel Commitee on Banking Supervision, the Financial Stability Board and the IMF.

For the theory of business cycles and also because the financial industry is a unstable market, it is difficult to think that thera will be no other imperfections.

\subsection{Macroeconomics maneuvres}

To get an idea of what the states would have to face, I report some ECB data of 2008: the bailout plan in Eurozona was 201 billion euro, 64 billion in other countries of EU and 683 billion in the United States. The state became the biggest shareholder of many banking system, expect Italy and Spain, which however have announced recapitalization plans. The state has purchased risky assets ang gave special safeguards. All this, has dramatically increased the assets of the central banks, but what is alarming is the quality of the assets of which are loaded the central banks. Now, they hold securities of longer maturity and more risky then those that have always characterized the central banks.

Economic crisis means rising of unempoyement, very low power consumption, low production and GDP dedreasing. These are the macroeconomic aspects on which the states and the central banks have to work. The financial institutions, also need help, for the fragility of their budgets and for the fact that the population has lost the trust in them. In this situation, is important to intervene on public spending through tax cuts, investment incentives and increase of public spending.

Compounding an economic crisis, there are also the psycological aspects of the population. The crisis have a negative damage and the state intervenes also to avoid the panic and the fear of the population. The fear and the mistrust have influed to the sale of bank shares. [5]

During the crisis, the demand for consumer goods is lowered by fear and uncertainty for the future and by the decrease of the income available to the public.

An expansionary policy of the government, which increase the demand for goods and services and therefore consumption (increase in government spending, tax cuts etc) ensure the input for the economic recovery ( more demand, more production for the business, hiring personnel etc).

Perhaps, the biggest problem of the population is the unempoyment. Citizens feel this effect directly and it spreads a feeling of helplessness and mistrust of the system. For the state is a problem to be solved as soon as possible also because more empoyees means more taxpayers, higher revenues and lower expenses for the unempoyees.

\section{There is still much to do}

To reform the financial system, "much remains to be done": so says the number one in the International Monetary Fund,Christine Lagarde, who emphasizes the role of central banks. "Do not come back to the world before the crisis: the new normal will be different," said Lagarde. According to Lagarde remain open three key issues: the fact that price stability is not always enough to ensure economic 
stability, the growing complex interconnections and the consequent financial difficulties for developing countries in managing large capital flows, also the need to reform the overall regulatory framework. Lagarde has therefore stressed the need "to reflect on the recent crisis and what we have learned" and the opportunity "to build stronger bridges between those who are concerned with the central banks." The Director of the Fund has finally remembered that on the face of the financial reform progress has been made "but that much remains to be done." [6]

"It 's next a new financial crisis," where the next does not mean in the next few days or in the next few weeks, but it indicates that the current trend is unsustainable financial markets with respect to economic growth and the level of indebtedness of the private and public Western economies. In fact, the bags continue to rise (the German Dax - index exceeded 10,000 points) and often shatter their all-time highs; capital markets are equally exuberant (remember that year bond yields of the French state have never been so low since 1740 and the Spanish ones since 1789); In addition there is also a craze for those who once called toxic assets (emissions collateralized loan obligations is reaching the levels before the financial crisis, the bonds issued to finance purchases of debt or other activities with high debt have reached the $\$ 1.6$ trillion); much of the financial review is conducted by the so-called shadow banking sector (private equity funds, hedge funds, investment funds, etc..) that are not regulated and are replacing banks true; and finally, the market volatility is very low. It is at all clear that this situation is the result of the monetary policies of central banks that have pushed down interest rates even in the medium and long term, but it is also clear that these trends are not sustainable in the light of the current context statement. Suffice it to say that according to the Institute of International Finance, which is funded by the big banks, the ratio of financial assets and GDP growth is deviating from its long-term trend. This means that if economic growth does not accelerate in the near future, the economy will not be able to create sufficient resources to finance the huge volume of financial assets outstanding (shares, bonds, etc..), Which will then undergo a strong downward correction.

We are in the presence of a mix of factors explosives. At first, the economic stagnation (in some European countries even a recession). Even the American economic growth is largely an optical illusion, as it continues to repeat the former Treasury Secretary Lawrence Summers, as it corresponds to the increase in population and the increase in productivity, while the median was down against the U.S. pre-crisis period of 2007-08.Secondly, inflation is very low (in the Eurozone fell to $0.5 \%$ ) and even the Old Continent in danger of slipping into deflation. Third, very low inflation makes it very difficult for European countries struggling to regain competitiveness needed to return to growth, because to achieve this must reduce wages and prices (though that is what is happening with the consequence of accelerating the times of falling into deflation and those away from a return to a growth path). Fourth, inflation makes it extremely difficult to reduce public and private debt (inflation has the effect of "miraculous" to reduce the stock of debt). So it makes it very painful that process of fiscal consolidation by the European Union and wanted to make terrible reduction of private debt, which is much higher in the public sector in many European countries (deflation make it impossible for this process by multiplying the corporate failures and individual). Fifth, interest rates are already at low levels and can't be reduced further.

All this "house of cards" standing thanks to the continuous injections of liquidity by central banks and the gullibility of investors who believe that the Federal Reserve and the European Central Bank have "magical powers" to ensure against any future mishap. But it is not. Then the house of cards is destined to fall. When? This year or early next year. WARNING: signals that the stability of the house of cards is increasingly in doubt are already on the way. [7]

\section{Conclusions}

Not only the crisis began in 2008 , there would still be weakened, but exist serious downside risks. There is a strong possibility that it opens a new crisis as the world is less able to meet its costs. Not only that. In short, as in 2008, many are underestimating the dangers (real) exist today in global finance. The problems are not so much by the growth of credit, which is relatively warm on the industrial markets while being stronger in emerging markets, as the prices of the assets related to financial risks. Financial crises are not predictable: the risks grow as long as you do not hit hard. 


\section{References}

1) Alesina, A. \& Giavazzi, F. (2008) The Crisis, Can the policy save the world?

2) Onado, M. (2008) The nodes in the comb. The financial crisis and the unwritten rules., Bari

3) Tabellini, G. A bad policy behind the market crisi, Il Sole 24 ore, 28 september 2008

4) Taylor John, B. (2008) The financial Crisis and the Policy Responses: An Empirical Analysis of What Went Wrong. The national Bureau of Economic Research

5) http://espresso.repubblica.it/opinioni/libero-mercato/2009/07/03/news/quanto-conta-lafiducia-1.14169

6) http://www.avvenire.it/Economia/Pagine/crisi-finanziaria-lagarde-molto-da-fare-.aspx

7) http://www.orticalab.it/Draghi-ripresa-fragile-non-siamo 